\title{
Research Paper Socio-economic impact of zero - till wheat in Pratapgarh, district of U.P.
}

\section{BHASKAR SHUKLA AND J. K. GUPTA}

See end of the paper for authors' affiliations

Correspondence to : BHASKAR SHUKLA Department of Agricultural Economics, Mahatma Gandhi Chitrakoot Gramoday Vishwavidyalaya, Chitrakoot, SATNA (M.P.) INDIA

Paper History : Received : 20.05.2016; Revised : 14.07.2016; Accepted : 13.08 .2016
Abstract : The zero- till wheat has significant impact in Pratapgarh district of Uttar Pradesh where sowing of wheat invariably delayed by 15 to 20 days resulting in reduction in yield can be avoided through ZT, due to 10-15 days earlier sowing than conventional method of wheat sowing, these findings are close conformity with findings of Sinha and Singh (2005). During study year 2013-14 it was observed that, on average the same crop yields are possible by zero-tillage compared to conventional tillage. The survey of 200 randomly selected zero tillage adopters and non-adopters has clearly established socio-cultural, psychological and economic gains by reflecting average grain production of zero-tillage $34.75 \mathrm{qt}$ and conventional tillage $33.11 \mathrm{qt} / \mathrm{ha}$. The percentage increase in wheat (grain) yield of zero-tillage over conventional tillage 4.95 per cent. The average yield of straw was recorded zero-tillage-37.65qt/ha and conventional $39.50 \mathrm{qt} / \mathrm{ha}$ which was 4.90 per cent less than conventional method and comparatively more economical technique in rice-wheat cropping system similar findings of Muhammad et al. (2011), crucial incentive for resource poor farmers. Further, the scanning of socio-economic data indicated that ZT technology had sense of achievement, merit for promotion, technical feasibility, stress reduction and opportunity for custom hiring services.

KEY Words : Zero-tillage, Conventional tillage, Socio-economic, Wheat

How To Cite This PAPer : Shukla, Bhaskar and Gupta, J.K. (2016). Socio-economic impact of zero - till wheat in Pratapgarh, district of U.P.. Internat. Res. J. Agric. Eco. \& Stat., 7 (2) : 164-168, DOI : 10.15740/HAS/ IRJAES/7.2/164-168. 